\title{
Pengaruh Pemberian Lemna Minor sebagai Pakan Sapi Perah terhadap Kadar Lemak, Berat Jenis, dan Bahan Kering tanpa Lemak Susu Friesian Holstein
}

\section{Effects of Giving Lemna Minor as Dairy Cattle Feed on Fat Levels, Density, and Solid Non Fat Milk of Friesian Holstein}

\section{U Hidayat Tanuwiria dan Raden Febrianto Christi}

Fakultas Peternakan Universitas Padjadjaran Jalan Raya Bandung-Sumedang Km 21, Jatinangor, Sumedang 45363, Jawa Barat. Indonesia

\author{
Article history \\ Received: Mar 29, 2020; \\ Accepted: Jul 27, 2020 \\ * Corresponding author: \\ E-mail: \\ uhtanuwir@yahoo.com \\ DOI: \\ 10.46549/jipvet.v10i2.102
}

\begin{abstract}
Lemna minor is a water plant that is easily obtained and has a good nutrient content that is high in protein. High protein for livestock can be used for production purposes. The study aims to determine the effect of administration of lemna minor on fat content, specific gravity, and dry matter without fat milk of friesien holstein dairy cows. The object of the study was 20 second-to-fourmonth FH lactating cows in the Dairy Farmer Group of Kp Tanggung Renteng Village, Pamegatan Village, Cikajang District, Garut Regency, West Java Province, then kept for 60 days and given feed according to treatment, namely $\mathrm{R} 0=$ Grass $60 \%+$ Concentrate $40 \%, \mathrm{R} 1=50 \%$ Grass $+40 \%$ Concentrate $+10 \%$ wet Lemna, R2 $=60 \%$ Grass $+37 \%$ Concentrate $+3 \%$ Dry Lemna, R3 $=50 \%$ Grass $+37 \%$ Concentrate $+10 \%$ Wet Lemna $+3 \%$ Dry Lemna, R4 = Grass $45 \%$ + Concentrate $38 \%$ + Wet Lemna $15 \%$ + Dry Lemna 2\%. The results showed that the effect of administering lemna minor did not affect on fat content, specific gravity, and dry matter without milk fat. The conclusion that administration of lemna minor in dairy cattle feed cannot increase fat content, specific gravity, and dry ingredients without fat Holstein friesien milk.
\end{abstract}

Keywords : Lemna minor; Fat content; Density; Solid non fat

\section{Abstrak}

Lemna minor merupakan tanaman air yang mudah diperoleh dan memiliki kandungan nutrient yang baik yaitu protein tinggi. Protein yang tinggi bagi ternak dapat dimanfaatkan untuk meningkatkan produksi. Penelitian bertujuan untuk mengetahui pengaruh pemberian lemna minor terhadap kadar lemak, berat jenis, dan bahan kering tanpa lemak susu sapi perah friesien holstein. Objek penelitian yang digunakan adalah 20 ekor sapi FH laktasi kedua sampai empat bulan di Kelompok Peternak Sapi Perah Kp Tanggung Renteng Desa Pamegatan Kecamatan Cikajang Kabupaten Garut Provinsi Jawa Barat kemudian dipelihara selama 60 hari dan diberikan pakan sesuai dengan perlakuan yaitu $\mathrm{R} 0=\mathrm{Rumput}$ $60 \%+$ Konsentrat 40\%, R1= Rumput 50\% + Konsentrat 40\% + Lemna basah $10 \%$, R2= Rumput $60 \%+$ Konsentrat 37\% + Lemna Kering 3\%, R3= Rumput $50 \%$ + Konsentrat 37\% + Lemna Basah 10\% + 3\% Lemna Kering, R4= Rumput $45 \%$ + Konsentrat 38\% + lemna basah 15\% + Lemna Kering 2\%. Hasil penelitian menunjukkan bahwa pengaruh pemberian lemna minor tidak berpengaruh terhadap $(\mathrm{P}>0,05)$ kadar lemak, berat jenis, dan bahan kering tanpa lemak susu. Kesimpulan bahwa pemberian lemna minor dalam pakan sapi perah tidak dapat meningkatkan kandungan lemak, berat jenis, dan bahan kering tanpa lemak susu friesien Holstein.

Kata kunci : Lemna minor; Kadar lemak; Berat jenis; Bahan kering tanpa lemak 


\section{PENDAHULUAN}

Negara Indonesia merupakan wilayah dengan potensi lahan yang cukup luas serta memiliki keanekaragaman flora dan fauna. Flora yang tumbuh subur di beberapa wilayah kepulauan ini memiliki banyak manfaat dan memiliki kualitas nutrisi yang cukup baik. Tanaman sumber hijauan pakan adalah salah satu bagian dari flora yang tumbuh pada berbagai macam media seperti tanah dan air. Tanaman yang dapat dijadikan sebagai pakan ternak tentu harus memiliki kualitas nutrisi yang baik. Tanah dan air sebagai media tempat tumbuh dan berkembangnya suatu tanaman sangat menentukan besar kecilnya nilai nutrient yang dimiliki. Seiring dengan berkembangnya waktu sekarang ini hijauan pakan di Indonesia relatif rendah, yakni protein, serat kasar tinggi, dan rendahnya mineral (Wanapat dan Rowlinson 2007).

Lemna minor adalah tanaman air yang tumbuh dengan cepat dan dijadikan sumber hijauan pakan bagi ternak yang berkualitas tinggi (Christi dan Tanuwiria, 2019). Selain itu tanaman ini banyak ditemukan dengan mudah di sungai dan dibudidayakan di beberapa wilayah seperti Jawa Barat, Yogyakarta, dan Nusa Tenggara Timur (Christi dan Tanuwiria, 2017). Kandungan protein kasar dari Lemna minor cukup tinggi. Kandungan protein kasar dari Lemna minor adalah 37,6\% dan serat yang relatif rendah yakni 9,3\% (Prasetyowati, 2016).

Populasi ternak sapi perah maupun produksi susu sapi nasional memperlihatkan kondisi yang semakin baik hal ini terlihat dari data pada setiap tahunnya. Tetapi perkembangan tersebut belum bisa mengimbangi permintaan dan konsumsi susu nasional yang juga semakin meningkat. Selain itu, faktor lain yang menyebabkan hal demikian adalah manajemen pemeliharaan yang dilakukan oleh peternak masih kurang seperti standar pemberian pakan yang diberikan kepada ternak untuk setiap periodenya terutama menjelang laktasi hingga akhir laktasi.

Tingginya kandungan protein kasar dalam lemna minor disinyalir mampu meningkatkan jumlah produktivitas dari seekor sapi perah dengan kualitas susu yang tinggi dapat dilihat dari komponen-kompoenen susu yang terkandung didalamnya seperti kadar lemak, laktosa, berat jenis, bahan kering, mineral, dan vitamin.

\section{MATERI DAN METODE}

Persiapan penelitian meliputi proses pembersihan dan peralatan kandang. Memilih sapi perah Friesien Holland $(\mathrm{FH})$ laktasi 2 dengan periode pemerahan antara bulan ke 2-4 sebanyak 20 ekor dengan bobot 400-500 kg. Tahapan penyesuaian terhadap pre-eliminary selama 14 hari sebelum diberikan perlakuan. Pakan yang diberikan berupa rumput gajah Mott dan limbah hasil pertanian berupa daun wortel dan daun kubis. Pakan diberikan 3 kali sehari yaitu pagi, siang, dan sore kecuali pemberian konsentrat yaitu dua kali. Pemberian air minum disediakan secara adlibitum. Konsumsi pakan dan sisa pakan ditimbang setiap hari. Produksi susu per hari diukur dengan mencatat hasil pemerahan pada pagi dan sore hari. Sampel diambil sebanyak 4 kali yaitu awal penelitian sebelum ternak diberi perlakuan, awal perlakuan, pertengahan perlakuan dan akhir penelitian untuk uji kualitas susu. Sampel susu diambil $\pm 50 \mathrm{~mL}$ dari masing-masing objek penelitian sesuai dengan perlakuan. Pengujian kualitas susu sapi FH meliputi berat jenis, kadar lemak, bahan kering tanpa lemak dengan Lactoscan di Laboratorium Kelompok Peternak Garut Selatan (KPGS Cikajang). Data hasil pengujian kemudian dilakukan pengolahan data dan dianalisis dengan Rancangan Acak Kelompok (RAK) 5 perlakuan dan 4 ulangan.

\section{HASIL DAN PEMBAHASAN}

\section{KADAR LEMAK}

Lemak merupakan bagian komposisi susu yang memiliki peran penting dalam indikator kualitas susu. Kandungan lemak tinggi menimbulkan rasa gurih pada susu dan olahannya hal ini karena lemak susu terdiri atas berbagai asam lemak. Semakin banyak lemak susu maka harganya pun akan semakin meningkat pula.

Kadar lemak susu pada masing-masing perlakuan secara umum masih berada pada kisaran normal yaitu 3-4\% (Standar Nasional Indonesia, 1998). Rataan kadar lemak pada perlakuan R3 memiliki nilai yang paling besar diantara R0, R1, R2, R4 yaitu 4,57\%. Menurut 
Riski (2016) Sapi perah FH yang diberikan pakan pelepah sawit dapat meningkatkan kadar lemak sebesar 3,05\%. Hasil analisis sidik ragam menunjukkan bahwa tidak ada perbedaan yang nyata $(\mathrm{P}<0,05)$ terhadap kadar lemak susu, namun terdapat fluktuasi dari data kadar lemak yang dihasilkan. Perlakuan dengan tambahan pakan berupa Lemna sp. memberikan dampak walaupun tidak berbeda nyata terhadap perubahan nilai lemak kasar pada setiap perlakuan terutama perlakuan R3 yaitu rumput $50 \%$, konsentrat $37 \%$, Lemna sp. basah $10 \%$, dan 3\% Lemna sp. kering.

Tabel 1. Pengaruh perlakuan terhadap lemak susu

\begin{tabular}{|c|c|c|c|c|c|}
\hline & R0 & R1 & $\mathbf{R 2}$ & $\mathbf{R 3}$ & $\mathbf{R 4}$ \\
\hline & \multicolumn{5}{|c|}{ |-------------------------- \% \%----------------------------- } \\
\hline 1 & 3.83 & 3.86 & 4.64 & 4.33 & 3.53 \\
\hline 2 & 4.80 & 3.88 & 4.09 & 4.03 & 5.22 \\
\hline 3 & 3.92 & 4.35 & 4.48 & 3.62 & 3.54 \\
\hline 4 & 4.15 & 4.01 & 3.59 & 6.32 & 4.71 \\
\hline Jumlah & 16,70 & 16,10 & 16,80 & 18,30 & 17,00 \\
\hline Rataan & 4,175 & 4,025 & 4,2 & 4,575 & 4,25 \\
\hline SD & 0,438 & 0,227 & 0,468 & 1,199 & 0,851 \\
\hline
\end{tabular}

Keterangan : R0 = Rumput $60 \%+$ Konsentrat $40 \%$

$$
\begin{aligned}
& \text { R1 }=\text { Rumput } 50 \%+\text { Konsentrat } 40 \%+\text { Lemna basah } 10 \% \\
& \text { R2 }=\text { Rumput } 60 \%+\text { Konsentrat } 37 \%+\text { Lemna Kering 3\% } \\
& \text { R3 }=\text { Rumput } 50 \%+\text { Konsentrat } 37 \%+\text { Lemna Basah } 10 \%+3 \% \text { Lemna Kering } \\
& \text { R4 }=\text { Rumput } 45 \%+\text { Konsentrat } 38 \%+\text { lemna basah } 15 \%+\text { Lemna Kering } 2 \%
\end{aligned}
$$

Berdasarkan Tabel 1. Nilai kandungan lemak pada perlakuan R3 menghasilkan yang paling tinggi karena sumbangan nutrien serat kasar dari dari bahan pakan yang diberikan pada ternak tinggi pula. Sedangkan perlakuan R4 secara analisis masih berada kisaran yang hampir sama dengan R3. Berbeda pada perlakuan R0, R1, dan R2 dimana terdapat perbedaan sumbangan nutrien serat kasar yang mempengaruhi lemak susu. Serat kasar yang rendah dapat menyebabkan kadar lemak susu menjadi rendah pula (Sudono, 1999). Karbohidrat seperti rumput dan Lemna sp. Dalam kondisi kering atau basah akan diproses di dalam rumen oleh mikroba menjadi produk energi yaitu Volatile Fatty Acid (Tanga et al., 2006). Produk tersebut menghasilkan asam asetat yang akan dimobilisasi pada sistem peredaran darah kemudian masuk pada sel-sel alveoli untuk pembentukan lemak susu (Soeharsono, 2008). Di samping itu, besar kecilnya suatu kadar lemak susu dipengaruhi frekuensi dan waktu pemerahan. Dilaporkan Penelitian Herawati (2003) bahwa terdapat perbedaan nilai kadar lemak pada pemerahan waktu pagi hari sebesar 5,23\% dibandingkan dengan pemerahan sore hari yaitu sebesar 5,5\% .

\section{BERAT JENIS}

Berat jenis menunjukkan imbangan komponen zat pembentuk seperti karbohidrat, protein, lemak, mineral, dan vitamin yang terkandung di dalam susu. Berat jenis susu dipengaruhi oleh kadar lemak dan BKTL yang tidak lepas dari pengaruh makanan dan kadar air dalam susu (Sidik, 2003).

Berat Jenis yang diukur dalam penelitian ini adalah susu dari tiap perlakuan yang diukur produksinya. Berat jenis susu sapi $\mathrm{FH}$ dapat dilihat pada Tabel 2. yang menunjukkan nilai rataan berat jenis susu sapi $\mathrm{FH}$ dengan kisaran 1,021 sampai dengan 1,023 Kg/L. Berdasarkan Tabel 2. berat jenis tertinggi diperoleh pada perlakuan R0 sedangkan R2, R3, R4 berada pada kisaran (\%) medium, dan $\mathrm{R} 1$ paling rendah. Hal ini dikarenakan pengaruh karbohidrat (SK dan BETN) terbesar berada pada R0 sedangkan perlakuan yang lain terdapat kecenderungan adanya kesamaan jumlah yang didapat. Dilaporkan Atmaja (2011) bahwa nilai berat jenis susu dipengaruhi oleh kandungan nutrient yang terdapat dalam bahan. Menurut Standar Nasional Indonesia (1998) bahwa minimum berat jenis susu pada sapi adalah 1,0280. Hasil sidik ragam menyatakan bahwa tidak terdapat perbedaan yang nyata $(\mathrm{P}<0,05)$ terhadap berat jenis susu. 
Gambar 19 menunjukkan bahwa perlakuan R0, $\mathrm{R} 1, \mathrm{R} 2, \mathrm{R} 3$, R4 menunjukkan hasil yang berfluktuasi. Hal tersebut Usmiati dan Nurdjanah (2007) bahwa berat jenis susu segar dipengaruhi oleh faktor pemberian pakan pada sapi tersebut. Pemberian pakan yang baik pada sapi perah akan berpengaruh besar terhadap kandungan-kandungan dalam susu tersebut begitu pula sebaliknya. Semakin tinggi persentase BK ransum maka akan menghasilkan berat jenis susu yang semakin besar pula. Berat jenis susu dipengaruhi oleh lemak karena BJ lemak lebih rendah dari pada air.

Tabel 2. Pengaruh perlakuan terhadap berat jenis susu

\begin{tabular}{|c|c|c|c|c|c|}
\hline & $\mathbf{R 0}$ & R1 & $\mathbf{R 2}$ & $\mathbf{R 3}$ & $\mathbf{R 4}$ \\
\hline & \multicolumn{5}{|c|}{-----------------------Kg/L ------------------------ } \\
\hline 1 & 1,025 & 1,019 & 1,024 & 1,022 & 1,023 \\
\hline 2 & 1,021 & 1,022 & 1,022 & 1,023 & 1,022 \\
\hline 3 & 1,023 & 1,024 & 1,022 & 1,023 & 1,023 \\
\hline 4 & 1,023 & 1,022 & 1,022 & 1,022 & 1,022 \\
\hline Jumlah & 4,092 & 4,087 & 4,090 & 4,090 & 4,090 \\
\hline Rataan & 1,023 & 1,021 & 1,022 & 1,022 & 1,022 \\
\hline SD & 0,002 & 0,002 & 0,001 & 0,001 & 0,001 \\
\hline
\end{tabular}

Keterangan : R0 = Rumput 60\% + Konsentrat 40\%

$$
\begin{aligned}
& \mathrm{R} 1=\text { Rumput } 50 \%+\text { Konsentrat } 40 \%+\text { Lemna basah } 10 \% \\
& \mathrm{R} 2=\text { Rumput } 60 \%+\text { Konsentrat } 37 \%+\text { Lemna Kering 3\% } \\
& \mathrm{R} 3=\text { Rumput } 50 \%+\text { Konsentrat } 37 \%+\text { Lemna Basah } 10 \%+3 \% \text { Lemna Kering } \\
& \mathrm{R} 4=\text { Rumput } 45 \%+\text { Konsentrat } 38 \%+\text { lemna basah } 15 \%+\text { Lemna Kering 2\% }
\end{aligned}
$$

Berat jenis susu yang rendah dipengaruhi oleh kadar lemak yang tinggi. Dilaporkan oleh Atmaja (2011) menyatakan bahwa berat jenis susu yang menurun dipengaruhi oleh faktor jenis makanan, perubahan kondisi kadar lemak, gas-gas yang timbul dalam susu, laktosa, protein, usia ternak, jenis ternak dan kesehatan lingkungan. Semakin tinggi nilai berat jenis susu maka semakin baik karena komposisi atau kandungan dari susu tersebut masih pekat dan kadar air dalam susu adalah kecil, sedangkan semakin banyak lemak pada susu maka semakin rendah berat jenisnya. Semakin berat susu maka banyak persentase bahan padat bukan lemak dalam susu tersebut (Utari et al., 2012). Komponen padatan susu dan BK konsentrat dalam ransum berkaitan langsung dengan berat jenis susu.

\section{BAHAN KERING TANPA LEMAK}

BKTL merupakan komponen bahan kering selain lemak seperti karbohidrat, protein, vitamin, dan mineral (Soeharsono, 2008). Kadar BKTL susu sangat bergantung pada kadar protein dan laktosa. Nilai BKTL disajikan pada Tabel 3.

Menurut Standar Nasional Indonesia (1998) bahwa kisaran BKTL susu yang baik adalah 7-8\%. Berdasarkan Tabel 3. menunjukkan bahwa BKTL susu yang dihasilkan masih berada pada kisaran normal. Hal tersebut terlihat pada Tabel 3. bahwa rataan BKTL susu tertinggi dicapai pada sapi yang mendapat perlakuan R0 dan R3 yaitu $7,702 \%$ dan 7,56\% sedangkan BKTL terendah dicapai pada sapi yang mendapatkan perlakuan R1 yaitu $7,33 \%$. Walaupun demikian pakan yang mengandung Lemna sp. memiliki pengaruh walaupun tidak berbeda nyata terhadap perubahan nilai BKTL. Menurut Ensminger dan Howard (2006) bahwa persentase BKTL susu sapi FH yang normal sebesar 8,35\%. Hasil sidik ragam menunjukkan bahwa tidak terdapat perbedaan yang nyata $(\mathrm{P}<0,05)$ terhadap BKTL susu namun terjadi fluktuasi terhadap kadar BKTL susu. Hal tersebut terlihat bahwa pada perlakuan R3 pemberian pakan lebih terjamin karena terdapat sumbangan hijauan dari Lemna sp. baik basah dan kering walaupun proporsi hijauan sedikit dikurangi. BKTL dalam susu terdiri atas karbohidrat, protein, vitamin, zat-zat nitrogen non protein dan mineral (Asminaya, 2007). Umumnya BKTL susu berkaitan dengan kandungan protein dan laktosa. Komponen bahan kering meliputi golongan karbohidrat, protein, vitamin, dan mineral (Tillman et al., 1998). Semakin tinggi protein dan laktosa dalam susu, maka diikuti oleh meningkatnya BKTL pula. Peningkatan kadar BKTL terjadi karena kadar lemak tidak 
termasuk pada bagian tersebut sehingga total protein dan laktosa yang tersisa dapat mempengaruhi tingginya persentase yang dihasilkan. Solid Non Fat (SNF) atau BKTL yang tinggi dipengaruhi juga oleh berat jenis yang terkandung dalam susu

Tabel 3. Pengaruh perlakuan terhadap Bahan Kering Tanpa Lemak Susu

\begin{tabular}{cccccc}
\hline & R0 & R1 & R2 & R3 & R4 \\
\hline & & ---------------------- & $\%-------------------------~$ & 7,60 \\
\hline 1 & 8,35 & 6,20 & 7,95 & 7,53 & 7,38 \\
3 & 7,24 & 7,34 & 7,41 & 7,82 & 7,65 \\
4 & 7,60 & 8,04 & 7,34 & 7,55 & 7,55 \\
\hline Jumlah & 7,62 & 7,77 & 7,44 & 30,26 & 30,18 \\
\hline Rataan & 30,81 & 29,35 & 30,14 & 7,565 & 7,545 \\
\hline SD & 7,702 & 7,337 & 7,535 & 0,190 & 0,117 \\
\hline
\end{tabular}

Keterangan : R0 = Rumput 60\% + Konsentrat 40\%

R1 = Rumput 50\% + Konsentrat 40\% + Lemna basah 10\%

R2 = Rumput $60 \%+$ Konsentrat $37 \%$ + Lemna Kering 3\%

R3 = Rumput 50\% + Konsentrat 37\% + Lemna Basah 10\% + 3\% Lemna Kering

R4 = Rumput 45\% + Konsentrat 38\% + lemna basah 15\% + Lemna Kering 2\%

\section{KESIMPULAN}

Pemberian lemna minor dalam pakan sapi perah tidak dapat meningkatkan kandungan lemak, berat jenis, dan bahan kering tanpa lemak susu friesien Holstein.

\section{UCAPAN TERIMA KASIH}

Ucapan terimakasih kepada HIVOS, Waghningen University, serta yayasan rumah energi yang telah membantu dalam melaksanakan penelitian ini sejak awal hingga akhir kegiatan.

\section{DAFTAR PUSTAKA}

Asminaya N. S. 2007. Penggunaan Ransum Komplit Berbasis Sampah Sayuran Pasar Untuk Produksi dan Komposisi Susu Kambing Perah. Fakultas Peternakan. Institut Pertanian Bogor, Bogor.

Atmaja S. 2011. Kasus Kesmavet. http://www.docstoc.com/docs//KasusKes mavet//. Diakses pada tanggal $12 \mathrm{Mei}$ 2011.

Christi R. F dan Tanuwiria U. H. 2019. Pengaruh Pemberian Lemna Minor Terhadap Produksi Susu Harian dan 4\% FCM Susu Sapi Perah Friesien Holstein. Jurnal Ilmiah Ilmu-Ilmu Peternakan Vol. 22(1):65-72.
Christi R. F dan Tanuwiria U. H. 2017. Pengeringan Tanaman Lemna minor Terhadap Kandungan Lemak Kasar dan Energi Bruto. Seminar Nasional Peternakan 3 Universitas Hasanuddin, Makkasar. Sulawesi Selatan.

Ensminger M. E and Howard D. T. 2006. Dairy Cattle Science. 4th Ed. The Interstate Printers and Publisher, Inc. Danville.

Herawati. 2003. Pengaruh Substitusi Porsi Hijauan Pakan Dalam Ransum dengan Nanas Afkir Terahadap Produksi dan Kualitas susu pada Sapi Perah Laktasi. Sekolah Tinggi Penyuluhan Pertanian Magelang. Magelang.

Tanga E. T, Rumetor S. D., and Rahardjo D. D. 2006. Sifat Fisik serta Kandungan Bahan Kering dan Bahan Organik Silase Rumput Irian (Sorghum sp) yang Difermentasi Menggunakan lsi Rumen. Jurnal Ilmu Peternakan dan Veteriner Tropis. 1(1):1-5. Tillman A.D., Hartadi H., Reksohadiprojo S., Prawirokusumo S. dan Lebdosoekojo S. 1998. Ilmu Makanan Ternak Dasar. Edisi Keenam. Gadjah Mada University Press. Yogyakarta.

Prasetyowati L. 2016. Pengaruh Variasi Penambahan Duckweed (Lemna Sp) Dalam Pakan dan Aplikasinya Sebagai Pakan Ikan Lele (Clarias Sp). Jurnal Agroteknose. Volume VII No. II. 
Riski. 2016. Pengaruh Penambahan Pelepah Daun Sawit Terhadap Produksi Susu FH. Universitas Hassanudin, Makkasar, Sulawesi Selatan.

Sidik R. 2003. Estimasi Kebutuhan Net Energi Laktasi Sapi Perah Produktif Yang Diberi Pakan Komplit Vetunair. Media Kedokteran Hewan. 19(3):135-138.

Soeharsono. 2008. Fisiologi Laktasi. Universitas Padjajaran, Bandung.

Standar Nasional Indonesia. 1998. Standar Mutu Susu Segar No. 01-3141-1998. Departemen Pertanian. Jakarta.

Sudono A. 1999. Ilmu Produksi ternak Perah. Jurusan Ilmu Produksi ternak. Fakultas Peternakan. Institut Pertanian Bogor. Bogor.

Usmiati S., dan Nurdjannah N. 2007. Perbandingan Kualitas Susu Sapi
Peternak Anggota Kud Sarwamukti dan Ksu Tandangsari: Studi Kasus. Seminar Nasional Teknologi Peternakan dan Veteriner.

Utari F. D., Prasetiyono B. W. H. E. dan Muktiani A. 2012. Kualitas Susu Kambing Perah Peranakan Etawa yang Diberi Suplementasi Protein Terproteksi dalam Wafer Pakan Komplit Berbasis Limbah Agroindustri. Animal Agriculture Journal, 1(1):427-441.

Wanapat M. and Rowlinson P. 2007. Nutrition and feeding of swamp buffalo: Feed resources and rumen approach. Presented at the VIII World Buffalo Congress, Organized by The International Buffalo Federation; Caserta Italy, 19-22 October 2007. 